San Jose State University

SJSU ScholarWorks

Doctoral Projects

Master's Theses and Graduate Research

Spring 5-2017

\title{
Attitudes and Perceptions of Advanced Practice Nurses towards Health Information Technology and Its Effects on Caring
}

Debbie Ramos Shih

California State University, Northern California Consortium Doctor of Nursing Practice

Follow this and additional works at: https://scholarworks.sjsu.edu/etd_doctoral

Part of the Family Practice Nursing Commons

\section{Recommended Citation}

Shih, Debbie Ramos, "Attitudes and Perceptions of Advanced Practice Nurses towards Health Information Technology and Its Effects on Caring" (2017). Doctoral Projects. 59.

DOI: https://doi.org/10.31979/etd.feqg-6esk

https://scholarworks.sjsu.edu/etd_doctoral/59

This Doctoral Project is brought to you for free and open access by the Master's Theses and Graduate Research at SJSU ScholarWorks. It has been accepted for inclusion in Doctoral Projects by an authorized administrator of SJSU ScholarWorks. For more information, please contact scholarworks@sjsu.edu. 


\section{ABSTRACT \\ ATTITUDES AND PERCEPTIONS OF ADVANCED PRACTICE NURSES TOWARDS HEALTH INFORMATION TECHNOLOGY AND ITS EFFECTS ON CARING}

Technology is rapidly, constantly evolving, and affecting healthcare. While it has the ability to improve healthcare outcomes, it is important to realize the impact this technology has on the relationships between patients and nurses (Korhonen, et al., 2015). Interactions with patients are increasing through computer technology and decreasing by physical presence and touch, potentially compromising the development of a trusting relationship and thus affecting patient quality outcomes (Sandelowski, 2002).

This cross sectional study explored the attitudes and perceptions of APRNs towards HIT and its effects on caring. 150 Advanced Practice Clinicians in a Northern California healthcare was surveyed, using the Information Technology Attitude Scales for Health (ITASH). Age, educational level, gender and ethnicity did not contribute any significant differences in the attitudes toward care value of information communication technology (ICT), training of ICT skills, ICT confidence or workload value. However, NPs compared to CNMs and PAs, had higher care value ICT score. Primary Care department also scored higher than Specialty Departments in the care value of ICT factor.

Debbie Ramos Shih

May 2017 
ATTITUDES AND PERCEPTIONS OF ADVANCED PRACTICE NURSES TOWARDS HEALTH INFORMATION TECHNOLOGY AND ITS EFFECTS ON CARING

\author{
by \\ Debbie Ramos Shih
}

\author{
A project \\ submitted in partial \\ fulfillment of the requirements for the degree of \\ Doctor of Nursing Practice \\ California State University, Northern Consortium \\ Doctor of Nursing Practice
}

May 2017 


\section{APPROVED \\ For the California State University, Northern Consortium Doctor of Nursing Practice:}

We, the undersigned, certify that the project of the following student meets the required standards of scholarship, format, and style of the university and the student's graduate degree program for the awarding of the master's degree.

Debbie Ramos Shih

Project Author

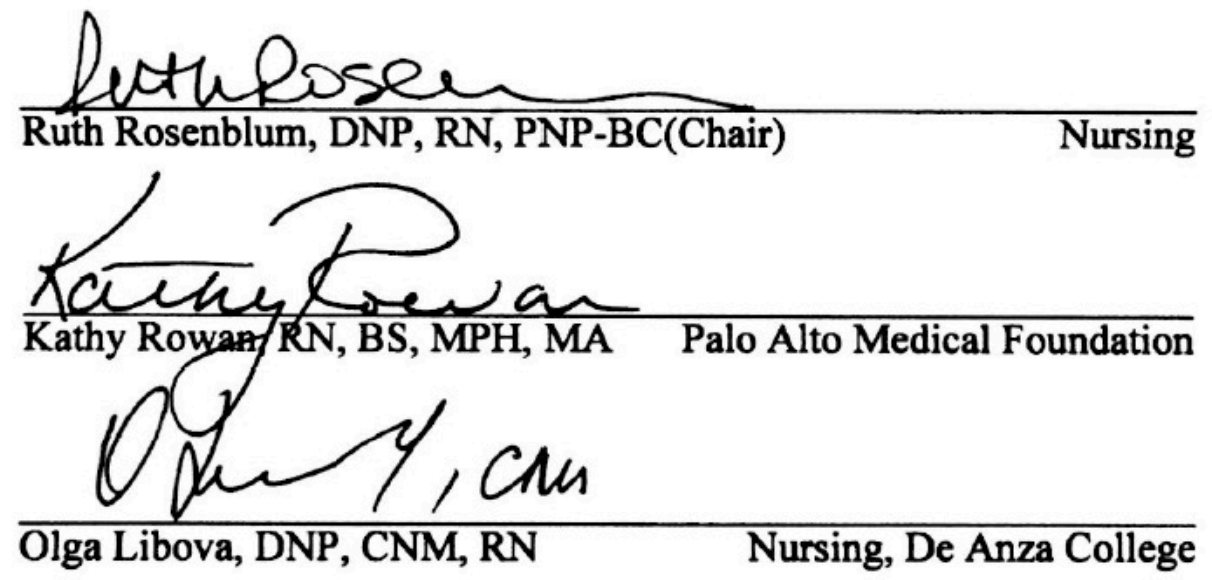




\section{AUTHORIZATION FOR REPRODUCTION}

\section{OF DOCTORAL PROJECT}

$\mathrm{X} \quad \mathrm{I}$ grant permission for the reproduction of this project in part or in its entirety without further authorization from me, on the condition that the person or agency requesting reproduction absorbs the cost and provides proper acknowledgment of authorship.

Permission to reproduce this project in part or in its entirety must be obtained from me.

Signature of project author: 


\section{ACKNOWLEDGMENTS}

Thank you for this opportunity to give thanks to God, who has constantly blessed me with opportunities to expand my nursing education and career; To my husband, Mason and children, Nathan and Elizabeth who have been very patient over the last 2 years of my "absence" when school needed to go first, and whose support and unconditional love I could not have done without; To my parents and family members who's encouragement and support helped me manage all the travels back and forth to China and California; To my Committee members: Dr. Ruth Rosenblum (Advisor and Project Chair), Dr. Olga Libova and Ms. Kathy Rowan, who's experience, feedback and support through this academic program helped me learn and grow both personally and professionally, well beyond what I expected; To my classmates, especially the Wonder Twins \& The Post It Laters, whose constant availability and support on Wechat allowed me to survive the program from China! To my friends and family in Shanghai, Northern California and Palo Alto Medical Foundation, who's presence and support in my life allowed this milestone to happen. I could not have done this without each and everyone of you behind me to push through! $\boldsymbol{W E}$ did it! 


\section{TABLE OF CONTENTS}

Page

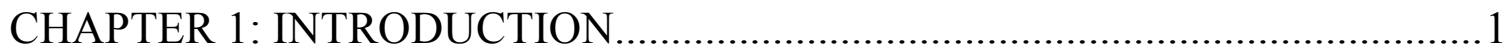

Key Terms and Definitions ....................................... 1

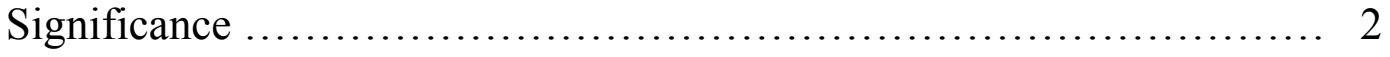

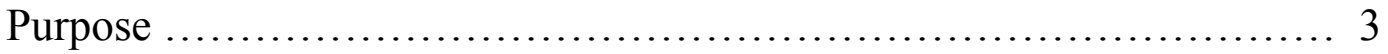

Theoretical Framework .............................................. 4

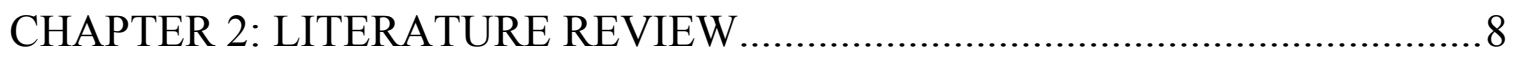

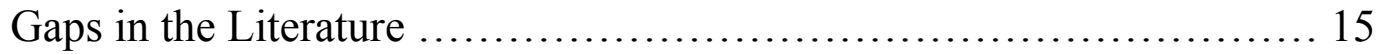

Information Technology Attitude Scales for Health (ITASH) ........... 16

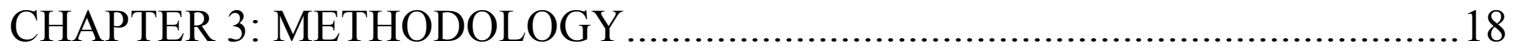

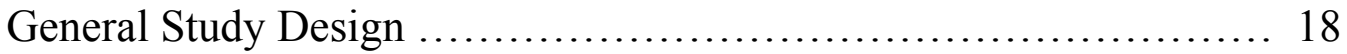

Methodology ................................................. 19

Risk/Benefits ................................................ 20

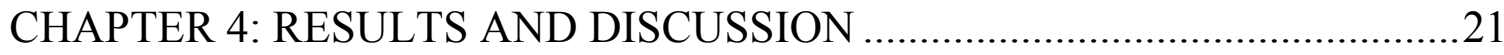

Data Analysis .............................................. 21

Descriptive Statistics ...................................... 22

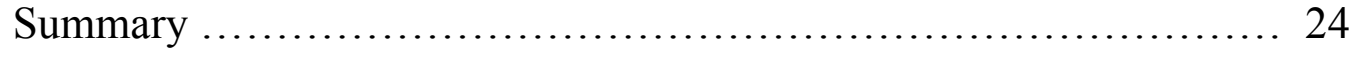

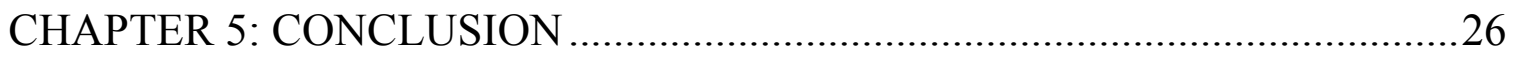

Outcomes/Discussion ......................................... 26

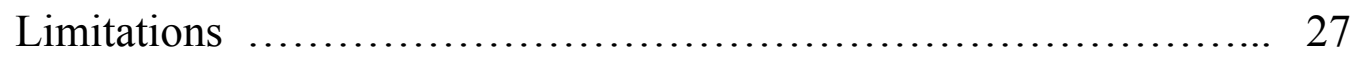

Implications for Nursing Practice ............................. 27

Recommendations for Further Study .......................... 27

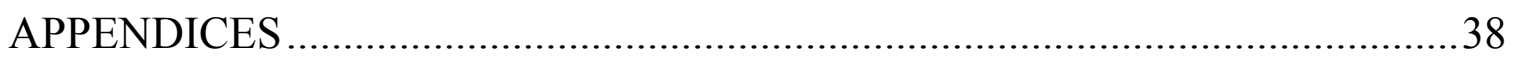

APPENDIX A: DEMOGRAPHICS/ITASH SURVEY ….....................................39 
APPENDIX B: OCCUPATION AND FACTOR 1 ANOVA $\ldots \ldots \ldots \ldots \ldots \ldots . . \ldots 5$

APPENDIX C: OCCUPATION AND FACTOR 2 ANOVA $\ldots \ldots \ldots \ldots \ldots \ldots . \ldots 50$

APPENDIX D: OCCUPATION AND FACTOR 4 ANOVA $\ldots \ldots \ldots \ldots \ldots \ldots . \ldots 55$

APPENDIX E: DEPARTMENT AND FACTOR 1 ANOVA ..................6 60 


\section{CHAPTER 1: INTRODUCTION}

Health Information Technology (HIT) and Communication Technology (CT) have proven to greatly impact health care in many different ways. They have increased efficiency in communication of information to other members of the healthcare team as well as to patients. There have been documented evidence of benefits from HIT and CT, such as greater adherence to health maintenance and preventive care guidelines, reduction in in-patient medication errors, and a decrease in cost of care (Hsu, 2005).

Caring is essential, if not the crux, of the nursing profession (Leininger, 1984; Watson, 1979). With the evolution of communication by technology, and health information technology used predominantly in today's health care system, one cannot help but question, if the sense of caring is compromised by this same technology (Sandelowski, 2002). By this, are we compromising the meaning of our nursing profession? Joanne Duffy, a nursing theorist, observed, that the foundation of caring behavior, skills and attitudes of professional nursing has been depreciated as the focus in health care today shifted to procedures and tasks, technology and cost containment (Duffy 2015). It is therefore important to consider how caring is impacted by this technology.

\section{Key Terms/Definitions}

\section{APC- Advanced Practice Clinician}

Physician Assistant, any APRN (Advanced Practice Registered Nurse) 
APN/APRN- Advanced Practice Nurse/Advanced Practice Registered Nurse

Nurse Practitioner (NP)

Clinical Nurse Specialist (CNS)

Certified Nurse Midwife (CNM)

Certified Nurse Anesthetist (CNA)

Health information Technology (HIT)- is a broad concept that encompasses an array of technologies to store, share, and analyze health information (EMR, PHI, e-tools, e-prescribing, Meaningful use).

Information/Communication Technology (ICT/CT)- ICT (information and communications technology - or technologies) is an umbrella term that includes any communication device or application, encompassing: radio, television, cellular phones, computer and network hardware and software, satellite systems and so on, as well as the various services and applications.

\section{Significance}

In today's world of healthcare and technology, it has become increasingly difficult to give patient undivided attention when some of the attention is on the computer screen. Often, health care providers have felt pressured by demands to be productive and yet deliver quality care without making the patient feel uncared for or ignored due to technology (Nagel, Pomerleau, \& Penner, 2013). Demands increase with patients wanting answers to questions by online messaging and explanation of their test results and prescriptions filled in a timely manner 
(Liederman, Lee, Baquero, \& Seites, 2005).

Much of the interaction with the patient is increasing through computer technology and decreasing by way of physical presence and touch (Sandelowski, 2002). Nursing and caring requires physical presence and touch in order for relationships to occur and it is through building these relationships that quality health outcomes happen (Korhonen, Nordman \& Eriksson, 2015; Malone, 2003; Nagel et al., 2013; Sandelowski, 2002). Technology is evolving rapidly and while it has the ability to improve healthcare outcomes, it is important to realize the impact this technology has on the relationships between patients and nurses (Korhonen, et al., 2015). Caring is changing in the face of technology for which creativity and innovation are indeed needed to continue the expression of genuine care and concern, not only by means of human contact, but now also by means of this technology (Hawkins, 2012; Nagel, et al., 2013).

\section{Purpose}

The purpose of this project is to explore and increase awareness regarding communication and expression of care in outpatient interactions while using computer technology. Further review of the literature is warranted to explore effects of HIT on advanced nursing practice and quality outcomes.

\section{Research Question(s)}

1) What are the perceptions and attitudes of Advanced Practice Nurses towards health information technology and its effect on caring? 
2) How has health information technology impacted the way Advanced Practice Nurses care for their served population?

\section{Implications}

Research has been done on hospital RNs', nursing students' and patients' perception and attitudes of technology and its effect on caring but not specifically to APNs. There is one study in the literature (Varghese, 2009), a naturalistic inquiry on caring and telehealth that explored attitudes and perceptions of APNs no quantitative studies for caring and technology. This study adds to the nursing literature and encourages further study. Results of this study can also guide nursing students in the understanding of caring and the influence of technology.

\section{Theoretical Framework}

Joanne R. Duffy developed the quality caring model in 2003. The purpose of this model was to expose the hidden work of nursing and support the link between nurse caring and quality health outcomes (Duffy, 2003). Duffy states that nurses have contributed much to the success of patient outcomes and increased patient satisfaction but that work is sometimes hidden or undocumented as to how much and what nurses actually do to achieve patient satisfaction and improved outcomes. Nurses have provided care around the clock across many settings, age and health continuum and it is time to quantify and expose the value of these services (Duffy, 2005; Duffy, 2013).

\section{Concepts and Propositions of Theory}


The four major concepts representing this theory include: Participants, caring relationships, feeling cared for and health. Participants are the patients, providers, the organization itself or anyone else that may be involved in the healthcare experience. Individuals are considered to have behaviors, attitudes, characteristics and life experiences that contribute or influence the meaning of their experiences, namely in health and illness (Duffy, 2015).

The four types of caring relationships encompassed in this theory are: self, patients and their families, each other, and communities. Caring relationships result in feeling care, leading then to self-advancement. This concept of selfadvancement was also later added to the revised quality caring model (Duffy, 2009).

Feeling cared for in turn is manifested by eight caring factors: attentive reassurance, basic human needs, encouraging manner, mutual problem solving, affiliation needs, healing environment, human respect, and appreciation of unique meanings (Duffy, 2009). Feeling cared for stimulates patients and their families to participate, learn and persevere toward better health outcome goals (Duffy, 2015).

These caring relationships make nurses' work more meaningful and satisfying and thus congruent with professional nursing values (Duffy, 2015). Job satisfaction influences productivity and performance and directly related to nurses' desire to work and provide quality health care (De Milt, Fitzpatrick, \& McNulty, 2011; Shea, 2008; Wild, Parsons, \& Dietz, 2006). 


\section{Theory Assumptions}

Assumptions of the revised Quality-Caring Model include:

1) Humans are multidimensional beings capable of growth and change.

2) Humans exist in relation to themselves, others, communities or groups, nature (or the environment), and the universe.

3) Humans evolve over time and in space.

4) Humans are inherently worthy.

5) Caring is embedded in the daily work of nursing.

6) Caring is a tangible concept that can be measured.

7) Caring relationship benefit both the carer and the one being cared for.

8) Caring relationships benefit society.

9) Caring is done "in relationship."

10) Feeling "cared for" is a positive emotion (Duffy, 2009, pp. 197-198).

The first four assumptions are regarding humans: Humans are higher, intelligent beings capable of evolving or growing by the process of learning. Humans are able to grow socially as well, in relationships with our communities and environment. According to monotheistic religions, humans beings are inherently worthy because we were created in the likeness and image of God.

Caring has been a very well studied topic in relation to nursing. Humans have the natural ability to care (Benner \& Wrubel, 1989; Edwards, 2001) and that caring is unique and central to nursing (Benner \& Wrubel, 1989; Leininger, 1984; Watson, 1979). Nursing cannot occur effectively without caring and it has been 
shown that relationships that develop between patient and healthcare provider, not only have measurable quality outcomes but also reciprocity in that the healthcare provider feels job satisfaction and professional growth (De Milt, et al., 2011; Duffy, 2015; Shea, 2008; Wild, et al., 2006). Caring can also extend to care of the community. Together, the community can grow together to support one another and build cohesion so that together they can contribute to one another's welfare and growth (Duffy, 2015). When one feels cared for, there is a contentment and ease and natural tendency to share this with others who are in need of this comfort. Humans have a natural desire to be cared for (Leininger, 1984). 


\section{CHAPTER 2: LITERATURE REVIEW}

\section{Introduction}

Existing studies that explore the attitudes of APRNs toward information technology are limited in that most studies are limited to registered nurses and not advanced practice nurses. These studies encompass attitudes of nurses as students or that of a specific specialty such as Intensive Care, Emergency Room, Surgical or Psychiatric. While some may be outdated, they were included here because of the study was important to include pertaining to the study of attitudes of APRNs toward technology and caring. The studies exploring caring and technology are also two very large topics and the literature is full of controversy surrounding how one should measure caring.

\section{Review of the Literature}

Brodel (2015) conducted a pre and post-test survey, examining nursing students' perceptions on caring, technology as caring, and technological influences on caring practice. Caring Attributes, Professional Self-concept Technological Influences (CAPSTI) Scale (Arthur et al., 1998; Watson, 2002) and the Technology Confidence Survey (Hess \& Heuer, 2003) were used to survey 80-90 students enrolled at Minot State University's Nursing Program during the fall of 2008 and spring of 2009 semesters. Significant correlations were found between and among the different parts of the CAPSTI. The designers established the Technology Confidence Survey validity through a process of expert reviews of the 
items and subsequent revisions. Results showed that students' perception of caring was high during the pretest and there was a minimal increase on the post-test. The students' perception of caring as a tool for technology suggests a need for more education on connecting technology and caring. Students also perceived that technology did not give them more time, but that it enhanced patient care and increased the professional status of nurses. This study was limited by convenience sampling and cannot be generalized to other nursing programs. However, the results of this study indicate a need to integrate technology and caring in nursing programs to prepare nurses for clinical practice.

In clinical practice, technology has posed some barriers to frontline nurses in adopting telehealth, as seen in the slow adoption rate of telehealth in the United Kingdom. Telehealth has been defined as, the remote exchange of data and information between patient and healthcare professional(s) to assist in diagnosis and management of health conditions (Sanders et al. 2012). Taylor (2014) conducted a thematic analysis of qualitative interviews to identify barriers to successful adoption of telehealth semi-structured interviews were conducted with 105 Registered Nurses located in 4 community clinics in the United Kingdom. Data was collected May 2012-June 2013 and included those RNs that used telehealth in chronic diseases, including Chronic Obstructive Pulmonary Disease and Chronic Heart Failure. The quality of the research was ensured using the criteria of dependability, credibility and authenticity. Framework analysis 
(Spencer et al. 2003) was used to structure and explore interview data. Face-toface interviews with audio-recordings were done at nurses' workplaces. Results of the study indicated that frontline staff acceptance of telehealth was fragile and uncertain and was hindered by organizational, professional, and technological barriers. This study added depth to the current understanding of factors affecting staff acceptance of telehealth but was limited in that findings were based on retrospective and somewhat partial accounts of implementation.

Using a quantitative, descriptive study design, Kinchen (2014) aimed to explore the development and testing of a new instrument designed to measure patients' perceptions of the holistic quality of nurse practitioner care. The Nurse Practitioner Holistic Caring Instrument (NPHCI), a 19-item, Likert-type scale and Swanson's (2002) Caring Professional Scale (CPS), were distributed by email to a convenience sample of adults recruited from the faculty and staff of seven academic colleges at Florida Atlantic University. Using selected strategies to establish preliminary validity and reliability levels of the instrument, Kinchen assessed psychometric soundness of the NPHCI. Cronbach's alpha was used to determine reliability of the instruments. 159 responses were included in the analysis. Data analysis, including sample demographics, exploratory factor analysis, reliability estimates, and correlations, was performed using SPSS (v.21.0). IBM Amos (v.21) was used for confirmatory factor analysis. Reliability estimates for the NPHCI were quite high; well over the suggested threshold of .70 
for a new instrument (Nunnally \& Bernstein, 1994). Results of this study revealed that patients found nurse practitioner care to exhibit attributes of holistic nursing care. Due to the newness of the instrument, further testing and psychometric evaluation were recommended.

Owens (2013) conducted a pre- and post-test, quantitative research study to determine if the creation of a specific education program for nurses, based on Jean Watson's Theory of Caring and her carative factors, would have a positive effect on incorporating and utilizing caring attributes as part of a daily nursing routine. This study surveyed 30 Registered Nurses on a 23-bed medical/surgical floor of 500-bed hospital serving a rural and urban community in the southeastern United States. Nyberg's Caring Assessment Scale (CAS), a 5-point Likert scale survey measuring caring factors was used. The reliability and validity of the CAS included a Cronbach's alpha reported at .87-.98. Pre-test and Post-test surveys using the CAS was administered with a 2-week education program on Watson's Theory. Descriptive statistics were used to determine the overall mean, median, and standard deviation of the difference in scores between the pre- and post-test. These variables were age, gender, nursing degree earned, and years of nursing experience. Regression statistics and ANOVA were used to determine the p-value of each of the demographic data categories. Results showed an average increase of 10.6 points from the pre- to post-test surveys, indicating positive results of the educational program based on Watson's Caring Theory. This study showed that 
by implementing an education program with Watson's Caring Theory and carative factors, daily bedside nursing care improved. The study was limited by having only 30 subjects and only 3 subjects out of the 30 were male.

Phenomenological designs are appropriate when exploring attitudes or perceptions of nurses regarding the effects of technology on caring. A phenomenological study by Bradley (2011) explored nurses' perceptions of the effects of electronic documentation on healing relationships. Eighteen Registered Nurses working in in-patient health care facilities located in Spokane, Washington, were interviewed. Sample demographics included 16 females and 2 males, with 13 out of the 18 working directly with patients. The remaining 5 were in managerial positions. Each semi-structured interview, performed at a site of the participant's preference, lasted 25-50 minutes and digital audio recordings of these interviews were reviewed. A modified van Kaam method using the Moustakas approach (1994) was used to determine themes from the verbal content. Drawing realistic conclusions from the participants' responses based on accurate, truthful data, and external review yielded credible interpretations. Sorting the data by NVivo $8.0 \circledR$ led to identification of themes and patterns and assisted in analyzing the qualitative research data. The four core themes of the study emerged as: 1 . Information technology, through ready availability of real-time patient health information, increases patient safety, facilitates trust, and strengthens nurse-patient relationships. 2. Trust promotes healing and is an important factor in nurse-patient 
relationships. 3. Patients need to feel cared for. 4. Nurses' use of information technology should not diminish caring behaviors. This study serves as a catalyst to allow leaders in healthcare organization to optimize the environment to facilitate the healing relationship between nurse and patient. One of the limitations of this study is that the researcher previously knew the participants.

Price (2013) used ethnography to explore and identify what enhances or inhibits registered health professionals' ability to care for patients within the technological environment of a critical care unit. At a District General Hospital intensive care unit, a sample of 19 participants took part in the study. Eight nurses were observed and 16 health care professionals were interviewed, including nurses, a doctor and 2 physiotherapists. The ICU experience of the participants ranged from 5 months to 20 years. Only 2 out of the 19 participants were male. Data was collected during day and night shifts from 2008-2009. Using constant comparative analysis, themes were used to link the caring and technological aspects. The themes included: crafting process, vigilance, and focus of attention, being present, and expectations. The end goal of these themes was achieving the best interest of the patient. This study highlighted that the concepts of caring and technology could not be separated but the way technology is delivered is important. However, the weakness of the study was that data were collected 20082009 and the ICU setting has since changed. 
McCance (2008) performed a quasi-experimental study, which used a measure of caring to evaluate and illustrate the connection between caring and patient-centeredness. A pre-test and post-test design was used to evaluate the effect of person-centered nursing on a range of outcomes. Dependent variables were job satisfaction, stress, staff retention, patients satisfaction with care, patients involvement in care, and nurses and patients perception of caring. The PersonCentered Nursing Index (PCNI) was the main data collection tool. The Caring Dimension Inventory (CDI) and Nursing Dimensions Inventory (NDI) were component parts of the PCNI and were used to measure nurses' and patients' perceptions of caring. The validity and reliability of the CDI and NDI have been previously tested (Watson \& Lea, 1997; Watson et al., 2001). The PCNI was administered at five points in time: once prior to the intervention phase (zero months) in order to obtain an accurate baseline measure and again at four specific time points over the two-year intervention period ( $4,8,12$, and 18 months). A patient sample from participating areas-an intensive care unit, a sexual health clinic, a rehabilitation ward, a pediatric unit, an infectious diseases ward, a medical admissions unit, a general surgery ward, a cardiology ward and an operating room-were randomly selected. Registered Nurses employed by the hospital, working in the aforementioned locations were also invited to participate in the study. Data were analyzed with the Mokken Scaling Procedure 3.0. SPSS 11.5 was used to generate graphic presentations of changes in items identified 
from the Mokken scaling procedure. Results showed a consistently high response rate over the period of the study with a good spread of gender and age groups. Calculating exact response rates from patients was difficult due to the nature of the questionnaire distribution for patients. Nurses had a clear idea of what constituted caring in nursing, with 12 'core' statements considered to be caring during all five data collection points. Comparison between the nurses' and patients' responses indicated a low degree of congruence, with only six items in common: 'listening to a patient', 'being with a patient during a clinical procedure', 'involving a patient in care', 'reporting a patient's condition to a senior nurse', 'observing the effects of medicine on a patient', and 'making a nursing record about a patient'. Incongruence between patients' and nurses' perception of caring was consistent with prior literature (Kyle, 1995). This study brought to light the differences in patient and nurse perceptions of the definition of caring. A limitation of the study was the lack of reporting clear response rates.

\section{Gaps in the Literature}

Review of the literature on the effects of HIT on caring is limited. There are many commentaries and systematic reviews of the literature indicating concerns about how technology affects caring, both positively and negatively. While there are many tools to measure caring, the definition of caring is obscure and therefore many controversies on how to interpret these measurements exist. Leininger (1977) and Watson (1988) state that caring cannot be operationalized 
and therefore quantitative studies are not suitable, while Kyle (1995) and Gaut (1983) state that it can be operationalized and so quantitative methods are appropriate.

There were no studies found in the literature specifically with Advanced Practice Nurses' perceptions or attitudes toward caring and effect of technology on caring. Measurement of nurses' attitudes toward ICT is difficult, greatly due to the complex and diverse factorial structures that influence attitudes Although studies may exist on tools that are available to explore attitudes towards technology, the report of their validity and reliability is inconsistent (Ward et al., 2008).

\section{Information Technology Attitude Scales for Health (ITASH)}

There are many instruments that have been used to assess nurses' attitudes towards technology, however, were noted to be inconsistent with results of studies and/or did not report reliability or validity (Ward et al., 2009, Lee \& Clarke, 2015). These tools included: The Nurses' Attitudes Toward Computerization (NATC) by Strong and Brodt (1985), Nurses Attitudes Inventory (NCATT) by Jayasuriya and Caputi (1996), Computer Attitude Scale (CAT) by Lloyd and Gressard (1984) and Technology Attitude Scale (TAS) by McFarlane et al. (1997). These tools were also created in the 1990's, which in the rapid pace of technological evolution, these would be inappropriate and outdated to use today (Lee \& Clarke, 2015). 
Rod Ward (2006) originally developed the Information Technology Attitude Scales for Health (ITASH). It is a 48-item questionnaire with acceptable reliability and validity (Ward et al., 2009). However, the length of the original ITASH makes it undesirable to use due to the time necessary to complete the whole questionnaire. Lee \& Clarke (2015) then developed a 19- item, shortened version of the ITASH (Appendix A) and was reported with acceptable reliability and validity. The shortened version is more appealing to potential participants as it is less time consuming.

Lee and Clarke's study (2015) was limited by its convenience sample of nursing students at a university in Seoul, Korea. Like that of other developed tools, there may or may not have been sufficient factors included that may influence attitudes toward ICT. The study also did not include factors such as age, gender and confidential issues (Ward et al, 2008). 


\section{CHAPTER 3: METHODOLOGY \\ General Study Design}

This is a cross sectional study of Advanced Practice Clinicians' attitudes and perceptions using descriptive research design to collect nominal and categorical data using frequencies and chi-square for analysis.

\section{Participants}

A convenience sample of a 150 Advanced Practice Clinicians within a nonprofit, multi-specialty, multi-location healthcare organization located in Northern California was surveyed. Inclusion criteria were an Advanced Practice Clinicians who has been employed for more than 3 months and has been working with health information technology for the same amount of time of at least 3 months.

Advanced Practice Clinicians is defined as nurse practitioners, certified nurse midwives and clinical nurse specialists, and physician assistants. Exclusion criteria are anyone not identified as an advanced practice clinician as defined in the inclusion criteria and who has not been using information technology for at least 3 months.

\section{Potential Problems with Subject Group}

Technology is rapidly evolving and re-training of a new system and crashing of an electronic system can bias the response to the surveys. The leadership structure is also constantly changing. Any change that affects or increases the stress of the subjects can potentially decrease the response rate and 
or influence the response to the survey. These are potential limitations to the study that are not within the control of the researcher.

\section{Methodology}

Information Technology Attitudes Scales for Health (ITASH), developed by Ward, et al., (2006) was disseminated to the 150-180 APCs via Survey Monkey (Appendix A). This method was chosen because PAMF is multi specialty and multi location and electronic means is more convenient for dissemination and return of the survey. Permission to use and adapt the ITASH (the shortened version) for the purposes of this study was granted by the author. (Survey attached as Appendix A).

A cover letter/consent form explained the importance and significance of the study and that participation is voluntary and confidential. This contained the link to survey monkey, which had demographic questions and ITASH survey. The Survey Monkey was used not only for data collection but also its quantitative analysis. Electronic survey and any other communication from the researcher to the participants occurred within the PAMF network using employee email addresses. Reminders were sent 2 weeks later to encourage increased participation. There was no labeling by name or number to provide confidentiality. The survey was disseminated directly to the APC by the primary investigator while the Associate VP of Organizational Effectiveness encouraged participation in the study. 


\section{Risks/Benefits}

There were no risks noted to the participants, however, participating in any study can potentially cause stress or anxiety while filling out survey.

Confidentiality was maintained by not linking any results to the participants through surveys disseminated by Survey Monkey. Only group results will be reported. There was no compensation offered to the participants volunteering to fill out the survey. 


\section{CHAPTER 4: RESULTS AND DISCUSSION}

\section{Results}

Out of a possible 150-180 Advanced Practice Clinicians, 64 responded (3544\%). The majority of the participants' age ranged 51-60 years of age was the highest (36\%), 41-50 years (28\%) and 31-40 years old at 20\%. The 61-70 year old at $11 \%$ and $20-30$ year old group was $5 \%$ of the participants.

Highest level of education was $75 \%$ having a Master's degree, $16 \%$ having a Bachelor's degree, $8 \%$ with an Associates Degree, and 1\% having a Doctoral Degree. The sample size consisted mostly of females (84\%) and $16 \%$ males. $50 \%$ of the participants were Nurse Practitioners, 44\% Physician Assistants, 5\% Certified Nurse Midwife and 1\% other, was noted to be a Nurse Educator. The Nurse Educator did not meet the inclusion criteria and had omitted the rest of survey, only answering the demographics questions. $65 \%$ of the participants worked in Specialty Areas, 19\% worked in Primary Care and 16\% other. Sample size consisted of mostly White (73\%), Asian/Pacific Islander (11\%), 5\% Hispanic/Latino, 2\% Native American Indian and 9\% other.

\section{Data Analysis}

SPSS version 23 was used for data analysis. The first part included demographic descriptive statistics followed by comparing the mean factor scores between ages, educational levels, genders, occupations, departments, and ethnicities. All of these were one-way ANOVA for each factor score, except for 
gender, which was a two-sample t-test for each factor score. If an ANOVA was statistically significant, Tukey's post hoc tests were applied to determine exactly which groups differed. A significant ANOVA only indicates that there is a difference somewhere between the groups, and the post hoc tests are needed to determine exactly which means differ. Descriptive statistics and power for each analysis were also performed.

\section{Descriptive Statistics}

The 4 factors in the ITASH survey assessed were: 1) Care Value of Information Communication Technology (ICT), 2) Training of ICT Skills, 3) ICT Confidence and 4) Workload Value of ICT. The four factors describe the conceptual domain: 'care value of ICT' that is a subscale measuring how APCs regard the contribution of ICT towards care; 'training of ICT skills,' which investigates the attitudes of APCs towards their ICT training and their desire for further ICT training; 'ICT confidence,' a subscale assessing APCs confidence in dealing with ICT; and the subscale, 'workload value of ICT' that examines their attitudes towards work efficiency in using ICT (Lee \& Clarke, 2015).

A separate analysis of variance (ANOVA) was done for each factor. Analysis of variance (ANOVA) on age compared each factor score between the age groups. The ANOVA compares the mean factor score between these age groups: $20-30$ years, $31-40$ years, $41-50$ years, $51-60$ years, and $61-70$ years. The means and standard deviations for the factor score are first given, and then the 
ANOVA results. For factor 1, Care Value of ICT, the statistical result is F $(4,54)$ $=2.007, \mathrm{p}=0.107$. Since the $\mathrm{p}$-value is greater than 0.05 , the result is not statistically significant, meaning that the mean factor score does not differ between ages. Lack of a significant difference between ages is seen for factors 2-4 as well.

The next set of results evaluates whether factor scores differ between educational levels (Associates Degree, Bachelors Degree, Doctoral Degree, and Masters Degree). Again, ANOVA determined that there were no statistically significant differences in factor 1-4 scores with the different educational levels. While the majority of APCs are educated at the Master's Level, there are programs for both NPs and PAs that are offered as a bridge from an AA/ADN (Associates of Arts/ Associate Diploma Nurse) to the Master's level for the NP program and Associates/Bachelor's and Master's degrees exist for the PA. These programs, although few, do still exist in the hopes of gaining a Master's level of education for all APCs.

Two-sample t-test is used instead of ANOVA to compare the differences in gender, female vs. males against factors 1-4. The p-values were greater than 0.05 , which means there were no noted difference in factor 1-4 score when comparing males and females.

Factor scores were compared between occupations using ANOVA. The comparison of Certified Nurse Midwives (CNMs) to Nurse Practitioners (NPs), p $=0.022$, differ on factor 1 . The mean factor 1 score is 2.667 for CNMs and 3.430 
for NPs, and the difference is statistically significant based on the p-value of 0.022. CNMs do not differ from PAs $(\mathrm{p}=0.369)$, and NP differs from PA $(\mathrm{p}=$ 0.009) with NP having a higher factor 1 score on average (Appendix B). Factor 3, scores do not differ between occupations, but they do for factors 2 (Appendix C) and 4 (Appendix D). Factor 2 score is 3.28 for NPs and 2.97 for PAs $(p=0.020)$ and Factor 4 score of 3.03 for NPs and 2.67 for PAs $(\mathrm{p}=0.037)$.

Factor 1 scores differ between departments $(\mathrm{p}=0.031)$, but factor 2,3 , and 4 scores do not differ between departments ( $p>0.05$ for each ANOVA). Primary care department scored a factor 1 score of 3.57, higher than Specialty department factor 1 score of 3.14 (Appendix E).

For ethnicity variable associated with factor 1-4, there are no statistical differences between ethnicities in any of the factors $1-4$ indicated by a $p>0.05$.

\section{Summary}

There are no significant differences in Factors 1-4 scores (Factor 1: Care Value of Information Communication Technology (ICT); Factor 2: Training of ICT Skills; Factor 3: ICT Confidence; Factor 4: Workload Value of ICT) with respect to age, educational level, gender and ethnicity. There were noted significant differences in Factor 1, 2, and 4 scores in the occupational category between CNM and NPs and between NP and PAs. NPs had higher factor 1 scores than both CNMs and PAs. NPs also scored higher than PAs in Factor 2 and 4 
scores. By departments, Primary Care department scored higher than Specialty departments in Factor 1 score. 


\section{CHAPTER 5: CONCLUSION}

\section{Outcomes/Discussion}

Literature suggests that there may be influences of gender, age and educational level to attitudes toward ICT. This study did not show any significant influence, which is consistent with the systemic literature review conducted by Ward et al. (2008). Workload factor in this study was also not affected by age, educational level, gender, ethnicity, specialty department or profession which is inconsistent with literature (Infinedo, 2016; Moody et al., 2004) in which, educational level and computer knowledge had positive effects on attitudes toward ICT. Infinedo (2016) also found that number of years nursing experience and age did not have meaningful results. Interestingly, Primary Care physicians felt an increased workload due to ICT in prior studies (Ward et al., 2008) whereas in this study, the workload was not affected or influenced by the different types of APCs (CNM, NP or PAs). However, by specialty departments, primary care department had higher care value ICT score than any other department.

The outcomes of this study suggests that NPs overall have a positive attitude regarding care value of ICT, training of ICT skills and workload value of ICT when compare to CNM and PAs. Health information technology, overall, has a positive impact on their served population and thus improved quality of care. This result is similar to the study by Moody, et al. (2004) in that medical errors due to order entry and legible charting improved healthcare outcomes. 


\section{Limitations}

This study has several limitations. This was a convenient sample of APCs in a healthcare organization located in Northern California. The results, therefore, cannot be generalized to any other location that may not have the same demographics or level of experience with health information technology. Moreover, the population may have been self selected to those interested in the topic of health information and communication technology, and due to location in Silicon Valley where technology is more advanced, the participants are heavily biased compared to the general population. The shortened version of the ITASH was also first used to evaluate attitudes of nursing students (Lee \& Clarke, 2014) and not advanced practice nurses in which the duties and experiences between them are quite different.

Upon further analysis, there seems to have been confusion as to what department they belonged in with regards to primary care, specialty or other. There were 10 responses to the "other" (indicating other departments not mentioned) and consisted of orthopedics, cardiovascular, behavioral health, palliative medicine, internal medicine, administrative, education, OB/GYN and urgent care departments. Definition of which department were considered specialty clinics could have been specified. Definition of what was considered ICT could have been included in the introduction as there may have been confusion on how technology pertained in their area of specialty. 


\section{Implications for Nursing Practice}

Technology and its increased use in the health care field is constantly evolving and changing. The attitudes of the end-users, such as advanced practice nurses, can impact the successful use of that technology (McGonigle \& Mastrian, 2014, Ward et al., 2008) and therefore need of constant monitoring. In so doing, educational and training needs of advanced practice nurses can be identified and addressed thus improving not only competency, but also job satisfaction, quality of care, and improved collaboration/team work (Ancker et al., 2013; De Milt, Fitzpatrick, \& McNulty, 2011; Jennings et al., 2014; Koivunen et al., 2015; Korhonen, Nordman, \& Eriksson, 2015).

\section{Recommendations for Further Study}

Due to the limitations mentioned, it is recommended that more research on attitudes towards information technology be conducted to identify other factors, educational needs that can strongly influence nursing practice and the healthcare industry as a whole. Further research can also place the new concept of nursing informatics more strongly in healthcare organizations creating a stronger voice for the nursing profession as a whole (McGonigle \& Mastrian, 2014). This study also occurred in Silicon Valley where most healthcare professionals have already been impacted by ICT. It would be interesting to see how attitudes may differ in more rural areas where technology in healthcare has not yet evolved rapidly or is just 
starting to be accepted as part of the healthcare industry. Most importantly, the rapidly evolving technology drives the need for constant assessment and evaluation of attitudes of end users in the healthcare industry to not only have that technology succeed but also improve patient quality outcomes. 


\section{REFERENCES}

Ancker, J., Silver, M., Miller, M., \& Kaushal, R. (2013). Consumer experience with and attitudes toward health information technology: a nationwide survey. Journal of the American Medical Informatics Association (20), $152-156$.

Arthur, D., Pang, S., \& Wong, T. (2001). The effect of technology on the caring attributes of an International sample of nurses. International Journal of Nursing Studies, 38(1), 37-43.

Arthur, D., Pang, S., Wong, T., Alexander, M., Drury, J., et al. (1999). Caring attributes, professional self-concept and technological influences in a sample of registered nurses in eleven countries. International Journal of Nursing Studies, 36(5), 387-396.

Benner P., \& Wrubel J. (1989) The primacy of caring, stress and coping in health and illness. Addison-Wesley Menlo Park, California.

Bornstein, M., Jager, J., \& Putnick, D. (2013). Sampling in developmental science: Situations, shortcomings, solutions, and standards. Developmental Review, 33(4), 357-370.

Bradley, S. (2012). A phenomenological exploration of nurses' perceptions of the effects of electronic documentation on healing relationships. Retrieved from ProQuest Dissertations and Theses database. (UMI No. 3506882). 
Brodell, E. (2009). Views of student nurses on caring and technology in nursing (Doctoral dissertation). Retrieved from ProQuest Dissertations and Theses database. (UMI No. 3406182).

De Milt, D., Fitzpatrick, J., \& McNulty, S. (2011). Nurse practitioners' job satisfaction and intent to leave current positions, the nursing profession, and the nurse practitioner role as a direct care provider. Journal of the American Academy of Nurse Practitioners, 23(1), 42-50.

Dextras-Gauthier, J., Marchand, A., \& Haines, V. (2012). Organizational culture, work organization conditions, and mental health: A proposed integration. International Journal of Stress Management, 19(2), 81-104.

Duffy, J. (2005). Implementing the quality-caring model@ in acute care. JONA: The Journal of Nursing Administration, 35(1), 4-6.

Duffy, J. (2005). Chapter 4: Want to graduate nurses who care? assessing nursing students' caring competencies. Annual Review of Nursing Education, 3, 5977.

Duffy, J. (2009). Quality caring in nursing : Applying theory to clinical practice, education, and leadership. New York: Springer Pub.

Duffy, J. (2015). Theories focused on caring. In J.B. Butts \& K.L. Rich, Philosophies and theories for advanced nursing practice $\left(2^{\text {nd }}\right.$ Ed), (pp.506513). Burlington, MA: Jones and Bartlett Learning. 
Edwards, S. (2001). Benner and Wrubel on caring in nursing. Journal of Advanced Nursing, 33(2), 167-171.

Eggenberger, T., Keller, K., Chase, S., \& Payne, L. (2012). A quantitative approach to evaluating caring in nursing simulation. Nursing Education Perspectives, 33(6), 406.

Ferguson, L. (2004). External validity, generalizability, and knowledge utilization. Journal of Nursing Scholarship, 36(1), 16-22.

Gaut, D. A. (1983). Development of a theoretical adequate description of caring. Western Journal of Nursing Research, 5, 313-323.

Hawkins, S. (2012). Telehealth nurse practitioner student clinical experiences: An essential educational component for today's health care setting. Nurse Education Today, 32(8), 842-845

Hess, C., \& Heuer, L. (2003) Technology confidence survey. (Available from HB Consultation \& Evaluation Associates, 1506 South 15th Street, Grand Forks, ND 58201)

Hsu, J., Huang, J., Fung, V., Robertson, N., Jimison, H., et al. (2005). Health information technology and physician-patient interactions: Impact of computers on communication during outpatient primary care visits. Journal of the American Medical Informatics Association, 12(4), 474-480.

Huston, C. (2013). The impact of emerging technology on nursing care: Warp speed ahead. Online Journal of Issues in Nursing, 18(2), 108. 
Infinedo, P. (2016). The moderating of demographic and individual characteristics on nurses' acceptance of information systems: a Canadian Study. International Journal of Medical Informatics, 87. 27-35.

Jayasuriya R, Caputi P (1996) Computer attitude and computer anxiety in nursing: validation of an instrument using an Australian sample. Computers in Nursing. 14, 6, 340-345.

Jennings, N., Clifford, S., Fox, A., O’Connell, J., Gardner, D. (2014). The impact of nurse practitioner services on cost, quality of care, satisfaction and waiting times in the emergency department: A systematic review. International Journal of Nursing Studies 52, 421-435.

Kinchen, E. (2015). Development of a quantitative measure of holistic nursing care. Journal of Holistic Nursing: Official Journal of the American Holistic Nurses' Association, 33(3), 238.

Koivunen, M., Anttila, M., Kuosmanen, L., Katajisto, J., \& Valimaki, M. (2015). Team climate and attitudes toward information and communication technology among nurses on acute psychiatric wards. Informatics for Health and Social Care, 40(1): 79-90.

Korhonen, E., Nordman, T., \& Eriksson, K. (2015). Technology and its ethics in nursing and caring journals. Nursing Ethics, 22(5), 561.

Kyle TV (1995) The concept of caring: a review of the literature. Journal of Advanced Nursing 21, 506-514. 
Lee, J., \& Clarke, C. (2015). Nursing students' attitudes towards information and communication technology: An exploratory and confirmatory factor analytic approach. Journal of Advanced Nursing, 71(5), 1181-1193.

Leininger, M. (1977). The phenomenon of caring. Part V. Caring: The essence and central focus of nursing. Nursing Research Report, 12, 2-14.

Leininger, M. M., ed. (1984) Care: The essence of nursing and health. Slack, New York.

Liederman, E., Lee, J., Baquero, V., \& Seites, P. (2005). Patient-physician web messaging: The impact on message volume and satisfaction. Journal of General Internal Medicine, 20(1), 52-57.

Loyd, B. \& Gressard, C. (1984) Reliability and factorial validity of computer attitude scales. Educational and Psychological Measurement. 44. 501-505.

Malone, R. (2003). Distal nursing. Social Science \& Medicine, 56(11), 2317.

McFarlane, T.,Green, K., \& Hoffman, E. (1997) Teachers' attitudes toward technology: Psychometric evaluation of the Technology Attitude Survey. Paper presented at the Annual Meeting of the American Educational Research Association in Chicago, IL. March 1997.

McGonigle, D., \& Mastrian, K. (2014). Nursing Informatics and the Foundation of Knowledge (3rd Edition). Sudbury, MA: Jones \& Bartlett Learning.

Moody, L., Slocumb, E., Berg, B. \& Jackson, D. (2004). Electronic records documentation in nursing. Computers, Informatics, Nursing 2, 337-44. 
Nagel, D., Pomerleau, S., \& Penner, J. (2013). Knowing, caring, and telehealth technology: "going the distance" in nursing practice. Journal of Holistic Nursing, 31(2), 104-112.

Nunnally, J., \& Bernstein, I. (1994). Psychometric theory (3rd ed.). New York, NY: McGraw Hill.

Owens, M. (2013). The effects of Watson's theory of caring and the nurse utilization of caring attributes (Master's thesis). Retrieved from ProQuest Dissertations and Theses database. (UMI No. 1548397).

Sandelowski, M. (2000). Combining qualitative and quantitative sampling, data collection, and analysis techniques in mixed method studies. Research in Nursing \& Health, 23(3), 246-255.

Sanders, C., Rogers, A., Bowen, R., Bower, P., Hirani S., Cartwright, M., Fitzpatrick, R., Knapp,M., Barlow J., Hendy, J., Chrysanthaki, T., Bardsley, M. \& Newman, S. (2012) Exploring barriers to participation and adoption of telehealth and telecare within the Whole System Demonstrator trial: a qualitative study. BMC Health Services Research 12, 220. doi:10.1186/1472-6963-12-220.

Shea, M. (2008). Determined persistence: Achieving and sustaining job satisfaction among nurse practitioners. n.p.: ProQuest Dissertations Publishing.

Spencer L., Ritchie J. \& O’Connor W. (2003) Analysis: practices, principles and processes. In Qualitative research practice: A guide for social science 
students and researchers (Ritchie J. \& Lewis J., eds), Sage, London, pp. 199-218.

Stronge, J. \& Brodt, A. (1985) Assessment of nurses' attitudes toward computerization. Computers in Nursing 3(4), 154-158.

Taylor, J., Coates, E., Brewster, L., Mountain, G., Wessels, B., Hawley, M. (2015). Examining the use of telehealth in community nursing: Identifying the factors affecting frontline staff acceptance and telehealth adoption. Journal of Advanced Nursing, 71(2), 326-337.

Varghese, S. (2009). A naturalistic inquiry on caring in telehealth (Doctoral dissertation). Retrieved from ProQuest Dissertations and Theses database. (UMI No. 3367485).

Ward, R., Glogowska, M., Pollard, K. \& Moule, P. (2006) Information technology attitude scales for health (ITASH): Project Report. University of the West of England, Bristol.

Ward, R., Glogowska, M., Pollard, K. \& Moule, P. (2009) Developing and testing attitude scales around IT. Nurse Researcher 17(1), 77-87

Ward, R., Stevens C., Brentnall P. \& Briddon J. (2008) The attitudes of health care staff to information technology: a comprehensive review of the research literature. Health Information \& Libraries Journal 25(2), 81-97.

Watson J. (1979) Nursing: The philosophy and science of caring. University Press of Colorado, Boulder. 
Watson, J. (2002). Assessing and measuring caring in nursing and health science. NewYork: Springer.

Watson, R., \& Lea., A. (1997). The caring dimensions inventory (CDI): content validity, reliability and scaling. Journal of Advanced Nursing 25, 87-94.

Watson, R., Deary, I., \& Hoogbruin, A. (2001) A 35-item version of the caring dimensions inventory (CDI -35$)$ : multivariate analysis and application to a longitudinal study involving student nurses. International Journal of Nursing Studies 38, 511-521.

Wild, P., Parsons, V., \& Dietz, E. (2006). Nurse practitioner's characteristics and job satisfaction. Journal of the American Academy of Nurse Practitioners, 18(11), 544-549. 
APPENDICES 
APPENDIX A: DEMOGRAPHICS/ITASH SURVEY 
Demographics:

Please choose the appropriate number that best describes you (choose ONE best answer).

1. My age is:

$$
\begin{aligned}
& 1 \text {-- 20-30 years old } \\
& 2 \text {-- 31-40 years old } \\
& 3 \text {-- 41-50 years old } \\
& 4 \text {-- 51-60 years old } \\
& 5 \text {-- 61-70 years old } \\
& 6 \text {-- greater than } 70 \text { years old }
\end{aligned}
$$

2. My highest educational level is:

$$
\begin{aligned}
& 1 \text {-- High School Diploma } \\
& 2 \text {-- Associates Degree } \\
& 3 \text {-- Bachelors Degree } \\
& 4 \text {-- Masters Degree } \\
& 5 \text {-- Doctoral Degree }
\end{aligned}
$$

3. I am:

$$
\begin{aligned}
& 1 \text { - Male } \\
& 2 \text {-- Female }
\end{aligned}
$$

4. I am:

$$
\begin{aligned}
& 1 \text {-- a Nurse Practitioner } \\
& 2 \text {-- a Certified Nurse Midwife } \\
& 3 \text {-- a Clinical Nurse Specialist } \\
& 4 \text {-- Physician Assistant } \\
& 5 \text {-- Other not mention }
\end{aligned}
$$

5. I mostly work in the department of:
2 -- Primary Care

3 -- Specialty Areas

4 -- Other not mentioned

6. My ethnicity is:

1 -- White

2 -- Hispanic or Latino

3 -- Black or African American

4 -- Native American or American Indian

5 -- Asian / Pacific Islander

6 -- Other 


\section{ITASH}

Information Technology Attitude Scales for Health

\begin{tabular}{cccc}
$\begin{array}{c}\text { Strongly } \\
\text { Disagree }\end{array}$ & Disagree & Agree & $\begin{array}{c}\text { Strongly } \\
\text { Agree }\end{array}$ \\
1 & 2 & 3 & 4 \\
\hline
\end{tabular}

1. Using ICT (Information

Communication Technology) devices is helping to improve patient/client care.

2. The sort of information I can get from 1 2 the ICT devices helps me give better care to patients.

3. Using ICT devices makes my communication with other health professionals faster.

4. I believe ICT devices can help us deliver individualized care.

5. I feel I need more training to use the ICT devices properly. to help me improve my ICT skills. 
$\begin{array}{lrr}\text { Strongly Disagree } & \text { Agree } & \begin{array}{r}\text { Strongly } \\ \text { Agree }\end{array} \\ \text { Disagree } & & \end{array}$

7. ICT skills are becoming more and more necessary for healthcare professionals.

8. In order to be successful in my career

1

2

3

4 I need to be able to work with ICT devices.

9. Using ICT devices helps to increase professionals' knowledge base.

10. I would like to know more about ICT devices generally.

12. I generally feel confident working with ICT devices.

13. I am easily able to learn new ICT skills.

14. I am often unsure what to do when using the ICT devices. 


\begin{tabular}{cccc}
$\begin{array}{c}\text { Strongly } \\
\text { Disagree }\end{array}$ & Disagree & Agree & $\begin{array}{c}\text { Strongly } \\
\text { Agree }\end{array}$ \\
1 & 2 & 3 & 4 \\
\hline
\end{tabular}

16. Where I work, ICT devices make staff less productive.

17. I feel there are too many ICT devices around now.

18. I think we are in danger of letting

1

2

3

4 ICT devices take over.

19. Time spent on ICT devices is out of 1 2 3 4 proportion to its benefits. 
APPENDIX B: OCCUPATION AND FACTOR 1 ANOVA 
Table 1 Descriptive Statistics

Dependent Variable: Factor 1

\begin{tabular}{|l|r|r|r|}
\hline I am a: & \multicolumn{1}{|c|}{ Mean } & Std. Deviation & \multicolumn{1}{|c|}{ N } \\
\hline Certified Nurse midwife & 2.6667 & .28868 & 3 \\
Nurse Practitioner & 3.4301 & .51239 & 31 \\
Physician Assistant & 3.0500 & .40182 & 25 \\
Total & 3.2302 & .50721 & 59 \\
\hline
\end{tabular}

Table 2 Levene's Test of Equality of Error Variances ${ }^{\mathrm{a}}$

Dependent Variable: Factor 1

\begin{tabular}{|c|c|c|c|}
\hline $\mathrm{F}$ & $\mathrm{df1}$ & $\mathrm{df} 2$ & Sig. \\
\hline 4.556 & 2 & 56 & . 015 \\
\hline
\end{tabular}

Tests the null hypothesis that the error variance of the dependent variable is equal across groups. ${ }^{\mathrm{a}}$

a. Design: Intercept + Occupation 
Table 3 Tests of Between-Subjects Effects

Dependent Variable: Factor 1

\begin{tabular}{|c|c|c|c|c|c|c|}
\hline Source & $\begin{array}{l}\text { Type III Sum } \\
\text { of Squares }\end{array}$ & $\mathrm{df}$ & Mean Square & $\mathrm{F}$ & Sig. & $\begin{array}{l}\text { Noncent. } \\
\text { Parameter }\end{array}$ \\
\hline $\begin{array}{l}\text { Corrected } \\
\text { Model }\end{array}$ & $3.003^{a}$ & 2 & 1.502 & 7.056 & .002 & 14.112 \\
\hline Intercept & 206.275 & 1 & 206.275 & 969.240 & .000 & 969.240 \\
\hline Occupation & 3.003 & 2 & 1.502 & 7.056 & .002 & 14.112 \\
\hline Error & 11.918 & 56 & .213 & & & \\
\hline Total & 630.549 & 59 & & & & \\
\hline Corrected Total & 14.921 & 58 & & & & \\
\hline
\end{tabular}

Table 4 Observed Power

Tests of Between-Subjects Effects

Dependent Variable: Factor 1

\begin{tabular}{|l|r|}
\hline Source & \multicolumn{1}{|c|}{ Observed Power } \\
\hline Corrected Model & \\
Intercept & \\
Occupation & 1.000 \\
Error & .916 \\
Total & \\
Corrected Total & \\
\hline
\end{tabular}

a. R Squared $=.201$ (Adjusted R Squared $=.173$ )

b. Computed using alpha $=.05$ 
Table 5 Estimated Marginal Means

I am a:

Dependent Variable: Factor 1

\begin{tabular}{|c|c|c|c|c|}
\hline \multirow[b]{2}{*}{ I am a: } & \multirow[b]{2}{*}{ Mean } & \multirow[b]{2}{*}{$\begin{array}{l}\text { Std. } \\
\text { Error }\end{array}$} & \multicolumn{2}{|c|}{$95 \%$ Confidence Interval } \\
\hline & & & $\begin{array}{l}\text { Lower } \\
\text { Bound }\end{array}$ & $\begin{array}{l}\text { Upper } \\
\text { Bound }\end{array}$ \\
\hline $\begin{array}{l}\text { Certified Nurse } \\
\text { midwife }\end{array}$ & 2.667 & .266 & 2.133 & 3.200 \\
\hline Nurse Practitioner & 3.430 & .083 & 3.264 & 3.596 \\
\hline Physician Assistant & 3.050 & .092 & 2.865 & 3.235 \\
\hline
\end{tabular}

Table 6 Post Hoc Tests

\section{Multiple comparisons}

Dependent Variable: Factor 1

Tukey HSD

\begin{tabular}{|l|l|l|l|r|}
\hline (I) I am a: & (J) I am a: & $\begin{array}{l}\text { Mean } \\
\text { Difference } \\
\text { (I-J) }\end{array}$ & $\begin{array}{l}\text { Std. } \\
\text { Error }\end{array}$ & \multicolumn{1}{|l|}{ Sig. } \\
\hline $\begin{array}{l}\text { Certified } \\
\text { Nurse } \\
\text { midwife }\end{array}$ & Nurse Practitioner & $-.7634^{*}$ & .27894 & .022 \\
\hline $\begin{array}{l}\text { Nurse } \\
\text { Practitioner }\end{array}$ & Physician Assistant & -.3833 & .28187 & .369 \\
\hline $\begin{array}{l}\text { Physician } \\
\text { Assistant }\end{array}$ & Certified Nurse Midwife & $.7634^{*}$ & .27894 & .022 \\
\hline
\end{tabular}


Table 7 Confidence Interval

\section{Multiple Comparisons}

Dependent Variable: Factor 1

Tukey HSD

\begin{tabular}{|l|l|r|r|}
\hline (I) I am a: & (J) I am a: & \multicolumn{2}{|c|}{$\begin{array}{l}\text { 95\% Confidence Interval } \\
\text { Lower Bound } \\
\text { Bound }\end{array}$} \\
\hline $\begin{array}{l}\text { Certified Nurse } \\
\text { Midwife }\end{array}$ & Nurse Practitioner & -1.4350 & -.0919 \\
& Physician Assistant & -1.0620 & .2953 \\
\hline $\begin{array}{l}\text { Nurse } \\
\text { Practitioner }\end{array}$ & $\begin{array}{l}\text { Certified Nurse } \\
\text { Midwife }\end{array}$ & .0919 & 1.4350 \\
\hline $\begin{array}{l}\text { Physician } \\
\text { Assistant }\end{array}$ & $\begin{array}{l}\text { Certified Nurse } \\
\text { Midwife }\end{array}$ & .0815 & .6787 \\
& Nurse Practitioner & -.2953 & 1.0620 \\
\hline
\end{tabular}

Based on observed means.

The error term is Mean Square (Error) $=.213$.

*. The mean difference is significant at the .05 level. 
APPENDIX C: OCCUPATION AND FACTOR 2 ANOVA 
Table 1 Descriptive Statistics

Dependent Variable: Factor 2

\begin{tabular}{|l|r|r|r|}
\hline I am a: & Mean & Std. Deviation & \multicolumn{1}{|c|}{ N } \\
\hline Certified Nurse midwife & 2.9444 & .67358 & 3 \\
Nurse Practitioner & 3.2753 & .44196 & 31 \\
Physician Assistant & 2.9693 & .33318 & 25 \\
Total & 3.1288 & .43220 & 59 \\
\hline
\end{tabular}

Table 2 Levene's Test of Equality of Error Variances ${ }^{\mathrm{a}}$

Dependent Variable: Factor 2

\begin{tabular}{|c|c|c|c|}
\hline $\mathrm{F}$ & $\mathrm{df1}$ & $\mathrm{df} 2$ & Sig. \\
\hline 3.319 & 2 & 56 & .043 \\
\hline
\end{tabular}

Tests the null hypothesis that the error variance of the dependent variable is equal across groups. ${ }^{\text {a }}$

a. Design: Intercept + Occupation 
Table 3 Tests of Between-Subjects Effects

Dependent Variable: Factor 2

\begin{tabular}{|l|r|r|r|r|r|r|}
\hline Source & $\begin{array}{c}\text { Type III } \\
\text { Sum of } \\
\text { Squares }\end{array}$ & df & \multicolumn{1}{c|}{$\begin{array}{c}\text { Mean } \\
\text { Square }\end{array}$} & \multicolumn{1}{c|}{ F } & Sig. & $\begin{array}{c}\text { Noncent. } \\
\text { Parameter }\end{array}$ \\
\hline $\begin{array}{l}\text { Corrected } \\
\text { Model }\end{array}$ & $1.403^{\mathrm{a}}$ & 2 & .701 & 4.164 & .021 & 8.329 \\
Intercept & 208.186 & 1 & 208.186 & $\begin{array}{r}1236.10 \\
3\end{array}$ & .000 & 1236.103 \\
Occupation & 1.403 & 2 & .701 & 4.164 & .021 & 8.329 \\
Error & 9.432 & 56 & .168 & & & \\
Total & 588.413 & 59 & & & & \\
Corrected & 10.834 & 58 & & & & \\
Total & & & & & \\
\hline
\end{tabular}

Table 4 Observed Power

Tests of Between-Subjects Effects

Dependent Variable: Factor 2

\begin{tabular}{|l|r|}
\hline Source & \multicolumn{1}{|c|}{ Observed Power $^{\mathrm{b}}$} \\
\hline Corrected Model & .711 \\
Intercept & 1.000 \\
Occupation & .711 \\
Error & \\
Total & \\
Corrected Total & \\
\hline
\end{tabular}

a. R Squared $=.129$ (Adjusted R Squared $=.098$ )

b. Computed using alpha $=.05$ 
Table 5 Estimated Marginal Mean

\section{I am a:}

Dependent Variable: Factor 2

\begin{tabular}{|c|c|c|c|c|}
\hline \multirow[b]{2}{*}{ I am a: } & \multirow[b]{2}{*}{ Mean } & \multirow[b]{2}{*}{ Std. Error } & \multicolumn{2}{|c|}{ 95\% Confidence Interval } \\
\hline & & & $\begin{array}{l}\text { Lower } \\
\text { Bound }\end{array}$ & Upper Bound \\
\hline $\begin{array}{l}\text { Certified Nurse } \\
\text { midwife }\end{array}$ & 2.944 & 237 & 2.470 & 3.419 \\
\hline Nurse Practitioner & 3.275 & .074 & 3.128 & 3.423 \\
\hline Physician Assistant & 2.969 & .082 & 2.805 & 3.134 \\
\hline
\end{tabular}

Table 6 Post Hoc Test

Multiple Comparisons

Dependent Variable: Factor 2

Tukey HSD

\begin{tabular}{|c|c|c|c|c|}
\hline (I) I am a: & (J) I am a: & $\begin{array}{c}\text { Mean } \\
\text { Differen } \\
\text { ce }(\mathrm{I}-\mathrm{J})\end{array}$ & $\begin{array}{l}\text { Std. } \\
\text { Error }\end{array}$ & Sig. \\
\hline \multirow[t]{2}{*}{$\begin{array}{l}\text { Certified Nurse } \\
\text { midwife }\end{array}$} & Nurse Practitioner & -.3308 & $\begin{array}{r}.2481 \\
4\end{array}$ & .383 \\
\hline & $\begin{array}{l}\text { Physician } \\
\text { Assistant }\end{array}$ & -.0249 & $\begin{array}{r}.2507 \\
5\end{array}$ & .995 \\
\hline \multirow[t]{2}{*}{ Nurse Practitioner } & $\begin{array}{l}\text { Certified Nurse } \\
\text { midwife }\end{array}$ & .3308 & $\begin{array}{r}.2481 \\
4\end{array}$ & .383 \\
\hline & $\begin{array}{l}\text { Physician } \\
\text { Assistant }\end{array}$ & $.3059^{*}$ & $\begin{array}{r}.1103 \\
2 \\
\end{array}$ & .020 \\
\hline \multirow[t]{2}{*}{ Physician Assistant } & $\begin{array}{l}\text { Certified Nurse } \\
\text { midwife }\end{array}$ & .0249 & $\begin{array}{r}.2507 \\
5\end{array}$ & .995 \\
\hline & Nurse Practitioner & $-.3059^{*}$ & $\begin{array}{r}.1103 \\
2\end{array}$ & .020 \\
\hline
\end{tabular}


Table 7 Confidence Interval

\section{Multiple Comparisons}

Dependent Variable: Factor 2

Tukey HSD

\begin{tabular}{|ll|r|r|}
\hline \multirow{2}{*}{ (I) I am a: } & \multicolumn{2}{|c|}{$95 \%$ Confidence Interval } \\
\cline { 3 - 4 } & (J) I am a: & $\begin{array}{c}\text { Lower } \\
\text { Bound }\end{array}$ & Upper Bound \\
\hline $\begin{array}{l}\text { Certified Nurse } \\
\text { midwife }\end{array}$ & Nurse Practitioner & -.9282 & .2666 \\
\hline Nurse Practitioner & Physician Assistant & -.6286 & .5788 \\
& Certified Nurse & -.2666 & .9282 \\
& midwife & .0403 & .5715 \\
\hline Physician Assistant & Pertified Nurse & -.5788 & .6286 \\
& midwife & -.5715 & -.0403 \\
\hline
\end{tabular}

Based on observed means.

The error term is Mean Square (Error) $=.168$.

*. The mean difference is significant at the .05 level. 
APPENDIX D: OCCUPATION AND FACTOR 4 ANOVA 
Table 1 Descriptive Statistics

Dependent Variable: Factor 4

\begin{tabular}{|l|r|r|r|}
\hline I am a: & \multicolumn{1}{|c|}{ Mean } & Std. Deviation & \multicolumn{1}{|c|}{$\mathrm{N}$} \\
\hline Certified Nurse midwife & 2.5333 & .50332 & 3 \\
& 3.0194 & .60300 & 31 \\
Nurse Practitioner & 2.6740 & .42158 & 25 \\
Physician Assistant & 2.8483 & .55156 & 59 \\
Total & &
\end{tabular}

Table 2 Levene's Test of Equality of Error Variances ${ }^{\mathrm{a}}$

Dependent Variable: Factor 4

\begin{tabular}{|r|r|r|r|}
\hline F & df1 & df2 & Sig. \\
\hline .841 & & 2 & \\
\hline
\end{tabular}

Tests the null hypothesis that the error variance of the dependent variable is equal across groups. ${ }^{\text {a }}$

a. Design: Intercept + Occupation 
Table 3 Test of Between-Subject Effects

Dependent Variable: Factor 4

\begin{tabular}{|c|c|c|c|c|c|c|}
\hline Source & $\begin{array}{l}\text { Type III } \\
\text { Sum of } \\
\text { Squares }\end{array}$ & df & $\begin{array}{l}\text { Mean } \\
\text { Square }\end{array}$ & F & Sig. & $\begin{array}{l}\text { Noncent. } \\
\text { Parameter }\end{array}$ \\
\hline $\begin{array}{l}\text { Corrected } \\
\text { Model }\end{array}$ & $1.964^{\mathrm{a}}$ & 2 & .982 & 3.507 & .037 & 7.015 \\
\hline Intercept & 166.863 & 1 & 166.863 & $\begin{array}{r}595.91 \\
6\end{array}$ & .000 & 595.916 \\
\hline Occupation & 1.964 & 2 & .982 & 3.507 & .037 & 7.015 \\
\hline Error & 15.681 & 56 & .280 & & & \\
\hline Total & 496.302 & 59 & & & & \\
\hline $\begin{array}{l}\text { Corrected } \\
\text { Total }\end{array}$ & 17.645 & 58 & & & & \\
\hline
\end{tabular}

Table 4 Observed Power

Tests of Between-Subjects Effects

Dependent Variable: Factor 4

\begin{tabular}{|l|r|}
\hline Source & \multicolumn{1}{|c|}{ Observed Power $^{\mathrm{b}}$} \\
\hline Corrected Model & \\
Intercept & .631 \\
Occupation & 1.000 \\
Error & .631 \\
Total & \\
Corrected Total & \\
\hline
\end{tabular}

a. $\mathrm{R}$ Squared $=.111$ (Adjusted R Squared $=.080$ )

b. Computed using alpha $=.05$ 
Table 5 Estimated Marginal Means

I am a:

Dependent Variable: Factor 4

\begin{tabular}{|l|r|r|r|r|}
\hline & & & \multicolumn{2}{|c|}{$95 \%$ Confidence Interval } \\
\cline { 4 - 5 } I am a: & Mean & Std. Error & Lower Bound & Upper Bound \\
\hline Certified Nurse & 2.533 & .306 & 1.921 & 3.145 \\
midwife & 3.019 & .095 & 2.829 & 3.210 \\
Nurse Practitioner & 2.674 & .106 & 2.462 & 2.886 \\
Physician Assistant &
\end{tabular}

Table 6 Post Hoc Tests

Dependent Variable: Factor 4

\section{Multiple Comparisons}

Tukey HSD

\begin{tabular}{|ll|r|r|r|}
\hline & \multicolumn{1}{|c|}{$\begin{array}{c}\text { Mean } \\
\text { Difference } \\
\text { (I-J) I am a: }\end{array}$} & $\begin{array}{c}\text { Std. } \\
\text { Error }\end{array}$ & \multicolumn{1}{c|}{ Sig. } \\
\hline $\begin{array}{llrl}\text { Certified Nurse } \\
\text { midwife }\end{array}$ & Nurse Practitioner & -.4860 & .31995 & .290 \\
& Physician Assistant & -.1407 & .32332 & .901 \\
\hline Nurse Practitioner & Certified Nurse & .4860 & .31995 & .290 \\
& midwife & $.3454^{*}$ & .14224 & .048 \\
& Physician Assistant & .1407 & .32332 & .901 \\
& Certified Nurse & $-.3454^{*}$ & .14224 & .048 \\
\hline
\end{tabular}


Table 7 Confidence Interval

\section{Multiple Comparisons}

Dependent Variable: Factor 4

Tukey HSD

\begin{tabular}{|ll|r|r|}
\hline \multirow{2}{*}{ (I) I am a: } & \multicolumn{2}{|c|}{$95 \%$ Confidence Interval } \\
\cline { 3 - 4 } Certified Nurse & Nurse Practitioner & $\begin{array}{c}\text { Lower } \\
\text { Bound }\end{array}$ & \multicolumn{1}{c|}{$\begin{array}{c}\text { Upper } \\
\text { Bound }\end{array}$} \\
midwife & $\begin{array}{r}\text { Physician Assistant } \\
\text { Nurse Practitioner }\end{array}$ & -.91963 & .2843 \\
& Certified Nurse & -.2843 & 1.2563 \\
& midwife & .0029 & .6878 \\
\hline Physician Assistant & -.6378 & .9191 \\
\hline Physician Assistant & Certified Nurse & -.6878 & -.0029 \\
& midwife & & \\
& Nurse Practitioner & &
\end{tabular}

Based on observed means.

The error term is Mean Square(Error) $=.280$.

*. The mean difference is significant at the .05 level. 
APPENDIX E: DEPARTMENT AND FACTOR 1 ANOVA 
Table 1 Descriptive Statistics

Dependent Variable: Factor 1

\begin{tabular}{|l|r|r|r|}
\hline $\begin{array}{l}\text { I mostly work in the } \\
\text { department of: }\end{array}$ & Mean & Std. Deviation & $\mathrm{N}$ \\
\hline Other (please specify) & 3.1786 & .42608 & 7 \\
Primary Care & 3.5694 & .43640 & 12 \\
Specialty Areas & 3.1375 & .50621 & 40 \\
Total & 3.2302 & .50721 & 59 \\
\hline
\end{tabular}

Table 2 Levene's Test of Equality of Error Variances ${ }^{\mathrm{a}}$

Dependent Variable: Factor 1

\begin{tabular}{|r|r|r|r|}
\hline F & df1 & df2 & Sig. \\
\hline .159 & & 2 & \\
\hline
\end{tabular}

Tests the null hypothesis that the error variance of the dependent variable is equal across groups. ${ }^{\text {a }}$

a. Design: Intercept + Department 
Table 3 Test of Between-Subjects Effects

Dependent Variable: Factor 1

\begin{tabular}{|l|r|r|r|r|r|r|}
\hline Source & $\begin{array}{c}\text { Type III } \\
\text { Sum of } \\
\text { Squares }\end{array}$ & df & $\begin{array}{c}\text { Mean } \\
\text { Square }\end{array}$ & \multicolumn{1}{c|}{ F } & Sig. & $\begin{array}{c}\text { Noncent. } \\
\text { Parameter }\end{array}$ \\
\hline Corrected & $1.743^{\mathrm{a}}$ & 2 & .872 & 3.704 & .031 & 7.409 \\
Model & 389.041 & 1 & 389.041 & 1653.24 & .000 & 1653.240 \\
Intercept & 1.743 & 2 & .872 & 3.704 & .031 & 7.409 \\
Department & 13.178 & 56 & .235 & & & \\
Error & 630.549 & 59 & & & & \\
Total & 14.921 & 58 & & & & \\
Corrected & & & & & \\
Total & & & & & & \\
\hline
\end{tabular}

Table 4 Observed Power

Tests of Between-Subjects Effects

Dependent Variable: Factor 1

\begin{tabular}{|l|r|}
\hline Source & \multicolumn{1}{|c|}{ Observed Power $^{\mathrm{b}}$} \\
\hline Corrected Model & .657 \\
Intercept & 1.000 \\
Department & .657 \\
Error & \\
Total & \\
Corrected Total & \\
\hline
\end{tabular}

a. R Squared $=.117$ (Adjusted R Squared $=.085$ )

b. Computed using alpha $=.05$ 
Table 5 Estimated Marginal Means

\section{I mostly work in the department of:}

Dependent Variable: Factor 1

\begin{tabular}{|c|c|c|c|c|}
\hline \multirow[b]{2}{*}{$\begin{array}{l}\text { I mostly work in the } \\
\text { department of: }\end{array}$} & \multirow[b]{2}{*}{ Mean } & \multirow[b]{2}{*}{$\begin{array}{l}\text { Std. } \\
\text { Error }\end{array}$} & \multicolumn{2}{|c|}{ 95\% Confidence Interval } \\
\hline & & & $\begin{array}{l}\text { Lower } \\
\text { Bound }\end{array}$ & $\begin{array}{l}\text { Upper } \\
\text { Bound }\end{array}$ \\
\hline Other (please specify) & 3.179 & .183 & 2.811 & 3.546 \\
\hline Primary Care & 3.569 & .140 & 3.289 & 3.850 \\
\hline Specialty Areas & 3.138 & .077 & 2.984 & 3.291 \\
\hline
\end{tabular}

Table 6 Post Hoc Tests

\section{Multiple Comparisons}

Dependent Variable: Factor 1

Tukey HSD

\begin{tabular}{|ll|r|r|r|}
\hline $\begin{array}{l}\text { (I) I mostly work in } \\
\text { the department of: }\end{array}$ & $\begin{array}{l}\text { (J) I mostly work in the } \\
\text { department of: }\end{array}$ & $\begin{array}{c}\text { Mean } \\
\text { Differenc } \\
\text { e (I-J) }\end{array}$ & $\begin{array}{c}\text { Std. } \\
\text { Error }\end{array}$ & Sig. \\
\hline $\begin{array}{l}\text { Other (please } \\
\text { specify) }\end{array}$ & Primary Care & -.3909 & .23071 & .216 \\
& Specialty Areas & .0411 & .19875 & .977 \\
\hline Primary Care & Other (please specify) & .3909 & .23071 & .216 \\
& Specialty Areas & $.4319^{*}$ & .15967 & .024 \\
\hline Specialty Areas & Other (please specify) & -.0411 & .19875 & .977 \\
& Primary Care & $-.4319^{*}$ & .15967 & .024 \\
\hline
\end{tabular}


Table 7 Confidence Interval

Dependent Variable: Factor 1

\section{Multiple Comparisons}

Tukey HSD

\begin{tabular}{|ll|r|r|}
\hline & & \multicolumn{2}{|c|}{$95 \%$ Confidence Interval } \\
\cline { 3 - 4 } $\begin{array}{ll}\text { (I) I mostly work in } \\
\text { the department of: }\end{array}$ & $\begin{array}{l}\text { (J) I mostly work in } \\
\text { the department of: }\end{array}$ & $\begin{array}{c}\text { Lower } \\
\text { Bound }\end{array}$ & \multicolumn{1}{c|}{$\begin{array}{c}\text { Upper } \\
\text { Bound }\end{array}$} \\
\hline Other (please specify) & Primary Care & -.9463 & .1646 \\
& Specialty Areas & -.4374 & .5196 \\
\hline Primary Care & Other (please specify) & -.1646 & .9463 \\
& Specialty Areas & .0475 & .8163 \\
\hline Specialty Areas & Other (please specify) & -.5196 & .4374 \\
& Primary Care & -.8163 & -.0475 \\
\hline
\end{tabular}

Based on observed means.

The error term is Mean Square (Error) $=.235$.

*. The mean difference is significant at the .05 level. 